\title{
Analisis Faktor Pemakaian Jasa Bantuan Hukum Probono Legal Aid di Pengadilan Agama Kelas 1A Tanjung Karang Kota Bandar Lampung
}

\author{
Abdul Qodir Zaelani \\ Universitas Islam Negeri (UIN) Raden Intan Lampung \\ abdulqodirzaelani@radenintan.ac.id
}

\begin{tabular}{l|l|l}
\hline Received: 03 Maret 2020 & Revised: 20 April 2020 & Approved: 04 Mei 2020 \\
\hline
\end{tabular}

\begin{abstract}
The purpose of this study is to uncover the factors underlying the use of probono legal aid legal aid services in the Class 1A Religious Court of Tanjung Karang, Bandar Lampung City. This research is a field research (field research), primary data taken from service users, service managers and officials in the Class 1A Religious Court of Tanjung Karang in Bandar Lampung City, through structured free interviews. This research found the fact that the presence of Legal Aid Posts which provide probono legal aid services is very helpful for people who need legal assistance because of their limitations with the factors that become the reasons for using legal aid services for probono legal aid. For those who do not understand the law, the presence of Posbakum in the Class 1A Religious Court of Bandar Lampung City is very helpful in the process of resolving legal issues, as well as for those who do not have sufficient budget and funds to resolve legal issues that are being passed through, the presence of Posbakum is very helpful and reduce their financial expenses. The presence of Posbakum also facilitates and accelerates the resolution of legal issues.
\end{abstract}

Keywords: Posbakum, Access to justice, Probono Legal Aid

Abstrak

Tujuan dari penelitian ini adalah mengungkap faktor-faktor yang melatarbelakangi pemakaian jasa bantuan hukum probono legal aid di Pengadilan Agama Kelas 1A Tanjung Karang, Kota Bandar Lampung. Penelitian ini merupakan penelitian lapangan (field research), data primer diambil dari para pemakai jasa, pengelola jasa 
dan pejabat di Pengadilan Agama Kelas 1A Tanjung Karang Kota Bandar Lampung, melalui wawancara bebas terstruktur. Penelitian ini menemukan fakta bahwa kehadiran Pos Bantuan Hukum yang memberikan jasa bantuan probono legal aid sangat membantu orang-orang yang membutuhkan bantuan hukum karena keterbatasan mereka dengan faktor yang menjadi alasan dalam menggunakan jasa bantuan hukum probono legal aid. Bagi mereka yang tidak mengerti tentang hukum, kehadiran Posbakum di Pengadilan Agama Kelas 1A Kota Bandar Lampung sangat membantu dalam proses menyelesaikan persoalan hukum, begitu juga bagi mereka yang tidak memiliki anggaran dan dana yang cukup untuk menyelesaikan persoalan hukum yang sedang dilaluinya, kehadiran Posbakum sangat membantu dan menekan pengeluaran keuangan mereka. Kehadiran Posbakum juga mempermudah dan mempercepat dalam penyelesaian persoalan hukum.

Kata Kunci: Posbakum, bantuan hukum, Probono Legal Aid

\section{Pendahuluan}

Setiap orang tanpa kecuali berhak mendapatkan peradilan yang adil dan tidak memihak (fair and impartial court). Hak ini merupakan hak dasar setiap manusia. Hak ini bersifat universal, berlaku di mana pun, kapan pun dan pada siapapun tanpa ada diskriminasi. ${ }^{1}$ Menciptakan keadilan, kedamaian, ketertiban, dan ketenteraman merupakan tujuan dari hukum. Dalam konteks ke-Indonesiaan, keadilan merupakan point penting dalam sistem kenegaraan. Hal ini terlihat dalam pembukaan UUD 1945, tepatnya tertulis di dalam 3 (tiga) alinea. Dari 3 (tiga) alinea tersebut, khusus dalam alinea IV, adil tertulis 1 (satu) kali, keadilan sosial tertulis 2 (dua) kali, sehingga secara keseluruhan tertulis 3 (tiga) kali. Selanjutnya, dalam Alinea I tertulis 1 (satu) kali dan dalam Alinea II tertulis 1 (satu) kali. Jadi, secara keseluruhan di dalam Pembukaan UUD 1945 tertulis 5 (lima) kali. Termuatnya keadilan dalam berbagai bentuk kata dalam Pembukaan UUD 1945 sebagai dokumen penting bagi negara, merupakan bukti bahwa keadilan hal yang penting dalam bernegara. ${ }^{2}$

Karenanya, negara dalam menjamin dan melindungi warga negaranya dari persoalan hukum, tidak mengenal strata, kedudukan, jabatan, jenis kelamin, agama dan ras. Semuanya mendapatkan perlakuan yang sama, termasuk di

${ }^{1}$ Irwantoni, Chaidir Nasution, Abdul Qodir Zaelani. 'Peranan Bantuan Hukum dalam Menyelesaikan Perkara di Pengadilan Agama (Studi di Pengadilan Agama Kelas LA Tanjungkarang Bandar Lampung)”. Asas,Vol. 10, No. 01 (2018), h. 122.

2 Ahmad Fadlil Sumadi. "Hukum dan Keadilan Sosial dalam Perspektif Hukum Ketatanegaraan Law and Social Justice in Constitutional Law Perspective”. Jurnal Konstitusi, Vol .12, No. 4 (2015),h. 864. 
dalamnya, mereka yang berada pada lingkaran kemiskinan. ${ }^{3}$ Perlakuan yang sama di hadapan hukum (equality before the law) dan persamaan perlakuan (equal treatment) merupakan bagian terpenting dalam negara hukum (rechtsstaat). ${ }^{4}$

Berdasarkan hasil penelitian, pemahaman masyarakat terhadap hukum atau regulasi yang dibuat oleh pemerintah, terkhusus masyarakat yang berada pada garis kemiskinan, berada pada posisi menengah ke bawah, terkait hak dan kewajiban dalam persoalan hukum, baik perdata maupun pidana, kerap kali mereka tidak mengetahuinya. ${ }^{5}$ Melihat kondisi demikian, kehadiran negara sangat dinantikan dan diperlukan bagi mereka yang memiliki minimnya pemahaman hukum. Negara hadir sebagai pelindung dan penjamin hak dan kewajiban mereka di mata hukum.

Begitu pentingnya kehadiran negara dalam persoalan tersebut, maka Mahkamah Agung dalam merespon empirisme di masyarakat, memberikan terobosan kebijakan melalui SEMA nomor 10 Tahun 2010. Inti dari SEMA tersebut, pemerintah wajib memberikan bantuan hukum kepada masyarakat pencari keadilan yang dipandang tidak mampu secara ekonomi, melalui regulasi atau aturan yang ada.

Dalam konteks bantuan hukum di Lingkungan Peradilan Agama, bantuan hukum tersurat dalam Lampiran B SEMA nomor 10 Tahun 2010 tentang Pedoman Bantuan Hukum di Lingkungan Peradilan Agama. Dalam lampiran B Pasal 1 ayat (4) disebutkan bahwa, bantuan hukum adalah pemberian jasa hukum yang difasilitasi negara melalui Peradilan Agama, baik dalam perkara perdata yang berkedudukan sebagai penggugat atau pemohon maupun sebagai tergugat atau termohon dengan mendapatkan hak diberikan pengacara prodeo. Sementara terkait Prodeo diatur dalam Peraturan Mahkamah Agung Republik Indonesia No. 1 Tahun 2014 tentang Pedoman Pemberian Layanan Hukum Bagi Masyarakat Tidak Mampu di Pengadilan, adalah proses berperkara di

${ }^{3}$ Sebagaimana dalam pasal 34 UUD 1945 bahwa, "Negara berkewajiban melindungi fakir miskin sebagai bagian dari warganya".

4Tata Wijayanta. "Bantuan Hukum Golongan Tidak Mampu dalam Perkara Perdata di Pengadilan Negeri Yogya". Mimbar Hukum,Vol. 24, No. 1 (2012) h. 111.

5 Direktorat Pembinaan Peradilan Agama Departemen Agama. Buletin Berkala Hukum dan Peradilan. (Jakarta: Departemen Pembinaan Badan Peradilan Agama Departemen Agama, 2002), h. 42. Berbagai penelitian terkait minimnya pemahaman masyarakat terhadap hukum atau regulasi yang dibuat pemerintah, di antaranya Laurensius Arliman Simbolon. "Partisipasi Masyarakat di dalam Perlindungan Anak yang Berkelanjutan Sebagai Bentuk. Kesadaran Hukum”.Padjajaran Jurnal Ilmu Hukum, Vol 3, No. 2, (2016), h. 310-329; Ersa Susanti, Adelina Hasyim, Yunisca Nurmalisa, "Pemahaman Masyarakat Terbadap Pembagian Waris Menurut Hukum Waris Islam di Desa Banjar Ratu”, http://jurnal.fkip.unila.ac.id, Vol. 5, No. 4, (2017). 
pengadilan secara cuma-cuma dengan dibiayai negara melalui anggaran Mahkamah Agung RI.

Secara konseptual, bantuan hukum merupakan jasa hukum baik litigasi dan non litigasi yang diberikan secara cuma-cuma kepada masyarakat yang dilakukan oleh orang profesional seperti advokat atau pengacara guna mendampingi hak-hak masyarakat yang membutuhkan jasa bantuan hukum. Sebagaimana secara substantif dijelaskan dalam UU No 16 Tahun 2011.

Konsep bantuan hukum dalam UU No 16 Tahun 2011 dan turut sertanya negara dalam penyelenggaraan bantuan hukum, sejalan apa yang dinyatakan Capplletti dan Gordley dalam artikel yang berjudul "Legal aid: modern themes and variations", sebagaimana dikutip Ade Irawan Taufik, yaitu pada dasarnya terdapat dua model (sistem) bantuan hukum, yaitu 'model yuridisindividual' dan 'model kesejahteraan', artinya bantuan hukum dapat dilihat sebagai suatu hak yang diberikan kepada warga masyarakat untuk melindungi kepentingan-kepentingan individu dan di lain pihak sebagai suatu hak akan suatu kesejahteraan yang menjadi bagian dari kerangka perlindungan sosial yang diberikan suatu negara. ${ }^{8}$

Terkait pelaksanaan bantuan hukum yang bersifat probono legal aid, beberapa akademis meneliti hal ini, seperti penelitian terkait implementasi pemberian bantuan hukum bagi rakyat miskin di Jawa Tengah berdasarkan Undang-Undang nomor 16 Tahun 2011 tentang bantuan hukum, ditemukan fakta bahwa UU tersebut berlaku efektif sejak Juli 2013. fakta di lapangan menyatakan bahwa pemberian bantuan hukum tidak dilakukan langsung oleh pemerintah. Bantuan hukum dilaksanakan oleh LBH atau organisasi kemasyarakatan. Pasal 2 Undang-Undang Bantuan Hukum mengatur bahwa pemberian bantuan hukum kepada penerima bantuan hukum diselenggarakan oleh menteri dan dilaksanakan oleh pemberi bantuan hukum berdasarkan undang-undang ini. ${ }^{9}$ Sementara dalam pasal 4 disebutkan dalam beberapa ayat. Ayat (1) bantuan hukum diberikan kepada Penerima Bantuan Hukum yang menghadapi masalah hukum. Ayat (2) bantuan Hukum sebagaimana dimaksud

${ }^{6}$ Lihat Irwantoni, Chaidir Nasution, Abdul Qodir Zaelani. "Peranan Bantuan Hukum dalam Menyelesaikan Perkara di Pengadilan Agama (Studi di Pengadilan Agama Kelas IA Tanjungkarang Bandar Lampung).'h. 123.

7 Diding Rahmat. "Implementasi Kebijakan Program Bantuan Hukum Bagi Masyarakat Tidak Mampu di Kabupaten Kuningan”, Jurnal Unifikasi, Vol. 04 No. 01 (2017), h. 38.

8 Ade Irawan Taufik. "Sinergitas Peran dan Tanggungjawab Advokat dan Negara dalam Pemberian Bantuan Hukum Cuma-cuma", Jurnal RechtsVinding: Media Pembinaan Hukum Nasional, Vol. 2 No. 2, (2013), h. 58.

${ }_{9}$ Yusuf Saefudin. "Implementasi Pemberian Bantuan Hukum bagi Rakyat Miskin di Jawa Tengah Berdasarkan Undang-Undang Nomor 16 Tahun 2011 Tentang Bantuan Hukum”. Jurnal Idea Hukum, Vol. 1, No. 1 (2015), h.68. 
pada ayat (1) meliputi masalah hukum keperdataan, pidana, dan tata usaha negara baik litigasi maupun non litigasi. Dan ayat (3) bantuan hukum sebagaimana dimaksud pada ayat (1) meliputi menjalankan kuasa, mendampingi, mewakili, membela, dan/atau melakukan tindakan hukum lain untuk kepentingan hukum Penerima Bantuan Hukum. ${ }^{10}$

Dalam catatan akademis, terdapat dua pengertian bantuan hukum dalam arti prabono dan bantuan hukum dalam pengertian legal aid. Stakeholder utama pemberi layanan hukum adalah advokat, dimana prabono menjadi salah satu strategi bagi advokat sebagai profesi terhormat (officium nobille) untuk membela kepentingan umum. Sedangkan konsep legal aid merujuk pada pengertian "state subsidizet', pelayanan hukum yang dibiayai atau disubsidi oleh negara. ${ }^{11}$

Sementara terkait eksistensi lembaga bantuan hukum, dalam artikel Legal Aid Democracy: Pengembalian Entitas Bantuan Hukum dalam Mewujudkan Aksesibilitas Hukum Bagi Masyarakat Indonesia dan Pembangunan Hukum Nasional menemukan fakta bahwa kehadiran lembaga bantuan hukum sebagai langkah strategis dalam mewujudkan aksesibilitas hukum bagi masyarakat Indonesia dan pembangunan hukum nasional. Beberapa langkah diambil oleh pemerintah yakni melakukan penguatan dan penegasan anggaran tentang bantuan hukum di APBN/APBD. Melakukan revisi UU Bantuan Hukum dan Advokat yang mencakup perluasan penerima bantuan hukum dengan menambahkan masyarakat marginal, perluasan ruang lingkup bantuan hukum dengan menambahkan pelanggaran hak asasi manusia ataupun hak konstitusional sebagai ruang lingkupnya serta melakukan deregulasi tentang sanksi advokat yang tidak menjalankan probononya tidak optimal. ${ }^{12}$

Data di atas menunjukkan bahwa kehadiran bantuan hukum dengan berbagai sumber anggarannya menjadi penting dalam upaya membantu masyarakat yang termarginalkan. Hanya saja, terkait artikel yang dibahas mengenai faktor pencari keadilan melalui jasa bantuan hukum probono legal aid belum ada yang membahasnya secara rinci dan detail. Karena itulah, penting kiranya mengkaji dan meneliti faktor pencari keadilan melalui pos bantuan hukum. Menjawab persoalan tersebut, fokus kajian ini dititikberatkan pada Pos

${ }^{10}$ Irwantoni, Chaidir Nasution, Abdul Qodir Zaelani. "Peranan Bantuan Hukum dalam Menyelesaikan Perkara di Pengadilan Agama (Studi di Pengadilan Agama Kelas LA Tanjungkarang Bandar Lampung)". h. 124.

11 Fachrizal Afandi. "Implementasi Pengabdian Masyarakat Berbasis Acces to Justice pada Lembaga Bantuan Hukum Kampus Negeri Pasca Pemberlakukan Undang-Undang Bantuan Hukum", Jurnal RechtsVinding: Media Pembinaan Hukum Nasional, Vo. 2, No. 1, (2013), h. 32.

12 Nisrina Atikah, Nurul Mutmainnah, Arif Rachman Nur. "Legal Aid Democracy: Pengembalian Entitas Bantuan Hukum dalam Mewujudkan Aksesibilitas Hukum Bagi Masyarakat Indonesia dan Pembangunan Hukum Nasional”. Universitas Hasanuddin Makassar 2015. 
Bantuan Hukum (Posbakum) di Pengadilan Agama Kelas 1A Tanjung Karang Kota Bandar Lampung.

Artikel ini merupakan hasil penelitian lapangan (field research). Artikel ini bersifat deskriptif analisis, yakni menggambarkan atau mendeskripsikan suatu objek untuk menemukan dan mengambil kesimpulan yang sifatnya umum. Sumber data yang digunakan dalam artikel ini adalah data primer dan sekunder. Data primer diambil dari Pengadilan Agama Kelas 1A Tanjung Karang Kota Bandar Lampung. Sementara data sekunder yang diambil adalah penjelasan dari data primer seperti buku atau jurnal yang relevan terhadap materi yang diambil dalam artikel ini. Teknik pengumpulan data melalui dokumentasi dan wawancara bebas terstruktur diambil dari Pengelola Posbakum, Panitera Muda Hukum, dan beberapa pengguna jasa Posbakum. Analisis data melalui deduktif, didasarkan pada pola penelitian yang bersifat umum kemudian ditarik kesimpulan dari arti yang khusus. ${ }^{13}$

Pembahasan

Pengadilan Agama di wilayah Lampung yang memiliki Posbakum hanya tiga yakni Pengadilan Agama Kalianda, Pengadilan Agama Tanjung Karang dan Pengadilan Agama Metro. Dalam proses penempatan personel Posbakum disesuaikan dengan regulasi yang dikeluarkan Mahkamah Agung Republik Indonesia.

Dalam konteks Pengadilan Agama Kelas 1ATanjung Karang, regulasi terkait pengelola Posbakum terus mengalami perubahan. Berdasarkan pernyataan Ahmad Burhanuddin, S.H.I., M.H.I., pada tahun ini (2017) system untuk pengelola Posbakum melalui system lelang, yakni layaknya system lelang pada umumnya. Untuk memenangkan lelang harus melalui beberapa tahapan yang telah ditentukan melalui LPSE. Salah satu tahapan yang harus dilalui adalah pembuktian kompetensi dan kelayakan dengan cara dites tiga soal yakni persoalan waris gugatan, permohonan penetapan ahli waris dan dispensasi nikah. Soal tersebut dibuat oleh Waka (Wakil Kepala) Pengadilan Agama Tanjung Karang Kelas 1 A sekaligus sebagai pengawas ujian. Lokasi ujian tersebut di ruang Waka Pengadilan Agama Tanjung Karang Kelas 1 A. Hal ini karena Waka Pengadilan Agama Tanjung Karang Kelas 1 A sebagai PPK yang mempunyai wewenang untuk mengawasi proses lelang tersebut, dalam hal ini adalah Drs. Ayat Saiful Miftah, S.H., M.H.

Pada saat itu kurang lebih tujuh Lembaga Bantuan Hukum mendaftar untuk mengisi Posbakum. Ketujuh Lembaga Bantuan Hukum tersebut di antaranya Asosiasi Pengacara Syariah Indonesia (APSI) Wilayang Lampung,

\footnotetext{
${ }^{13}$ Sutrisno Hadi. Metodologi Research. Jilid I (Yogyakarta:PT. Andi Offset, 1989), h. 42.
} 
LBH AFTA dan lainnya. Ketujuh Lembaga Bantuan Hukum tersebut diwakilkan satu orang untuk mengerjakan soal-soal tersebut yang sudah disiapkan panitia. Peserta lelang yang mengikuti tes tersebut harus mengerjakan soal dalam waktu 120 menit atau selama 2 jam.

Pemenang lelang tersebut pada tahun 2017 adalah antaranya Asosiasi Pengacara Syariah Indonesia (APSI) Wilayah Lampung. APSI Wilayah Lampung selain sukses mengerjakan soal-soal yang diujikan, juga satu-satunya Lembaga Bantuan Hukum yang lolos kualifikasi administrasi. Maka pada tanggal 28 Maret 2017 APSI Wilayah Lampung resmi mengelola Posbakum hingga 31 Desember 2017. Untuk tahun selanjutnya akan dilakukan proses lainnya untuk mengisi Posbakum, bisa saja melalui lelang atau juga penunjukan.

Menurut Ahmad Burhanuddin, S.H.I., M.H.I., sebelum tahun 2017 proses penempatan pengelola Posbakum berbeda-beda. Pada tahun 2016 pengelola Posbakum melalui penunjukkan, pada saat itu yang ditunjuk adalah Syekh Syarif Hadaiyatullah, M.H.I., dan Dharmayani, M.H.I. Sebelumnya, pada tahun 2013-2016, pengelola Posbakum diserahkan kepada IAIN (UIN) Raden Intan Lampung. Sementara pada tahun 2012 pada saat itu sebagai Kepala Pengadilan Agama Tanjung Karang Kelas 1A, Drs. Khalis, pengelola Posbakumnya dari Peradi (Perhimpunan Advokat Indonesia). ${ }^{14}$

Data Pemakai Jasa Bantuan Hukum (Posbakum)

Selama tahun 2017, saat APSI Lampung sebagai pengelola Posbakum yang dimulai aktif bulan April, data pemohon yang memakai jasa Posbakum bersifat fluktuatif. Tercatat data yang masuk pada bulan April sebanyak 94 orang, bulan Mei sebanyak 78 orang, bulan Juni sebanyak 33 orang, bulan Juli sebanyak 153 orang, bulan Agustus sebanyak 109 orang, bulan September sebanyak 121 orang, bulan Oktober sebanyak 122 orang, dan hingga pertengahan November saat ini berjumlah sebanyak 72 orang. Bila dijumlahkan keseluruhan, maka pemakai jasa Posbakum Pengadilan Agama Kelas 1A Tanjung Karang sebanyak 782 orang.15

14 Wawancara dengan Ahmad Burhanuddin, S.H.I., M.H.I., pengacara Posbakum Pengadilan Agama Klas 1A Tanjung Karang, Kota Bandar Lampung pada Rabu 15 November 2017. 


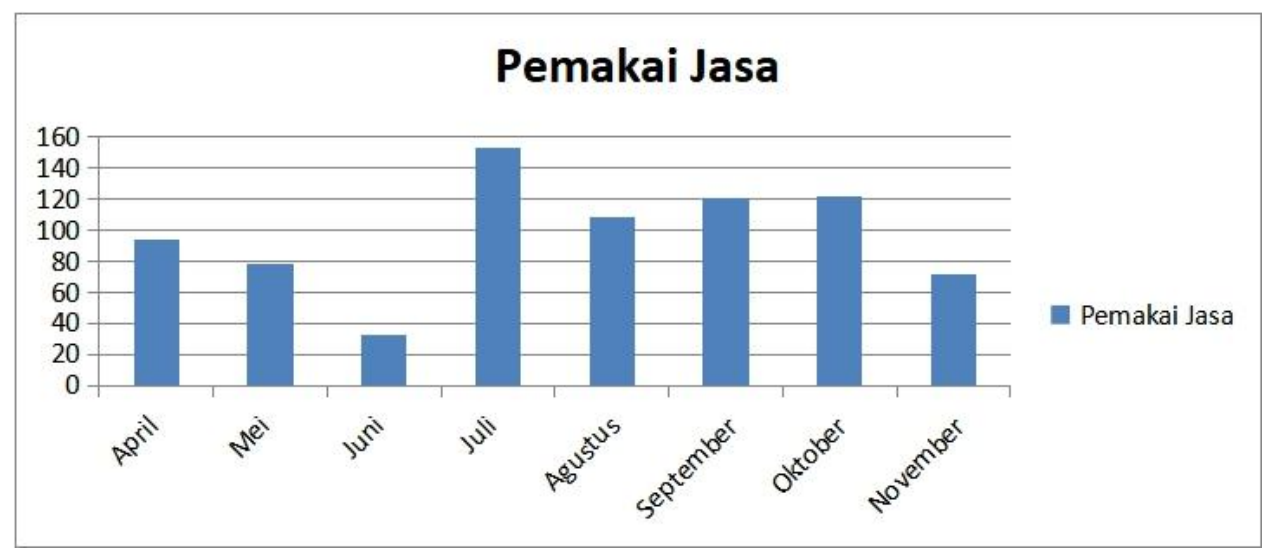

\section{Peranan Bantuan Hukum dalam Menyelesaikan Perkara di Pengadilan Agama}

Menurut Syukur, S.Ag., M.H., Panitera Muda Hukum, menyatakan kehadiran Posbakum merupakan batu loncatan untuk para pemohon dalam memproses perkaranya, yang kemudian disidangkan, dan hasil dari persidangan akan diarsipkan oleh bagian panitera muda hukum. Walaupun sebenarnya, dalam memproses perkara, pemohon bisa melakukan dengan memilih tiga cara yakni dengan cara melakukan sendiri, posbakum, dan pengacara (professional dan kuasa insidentil).

Syukur, S.Ag., M.H., menjelaskan tata cara ketiga hal tersebut. Cara pertama, melakukan sendiri tanpa Posbakum dan pengacara jika pemohon adalah seseorang yang mengerti hukum dan dapat membuat surat permohonan atau gugatan sendiri, tahu bagaimana membuat surat gugatan, di antaranya mengerti tentang posita dan petitum. Posita dalam gugatan terkait dengan kronologis kasus yang bermuatan hukum, sementara petitum adalah tuntutan dari gugatan seperti menuntut untuk cerai, menuntut hak asuh anak, menuntut pembagian harta gono gini dan lainnya berkaitan dengan tuntutan gugatan.

Cara kedua, melalui posbakum, sebagai tempat bertanya dan konsultasi hukum bagi mereka yang tidak mengerti terkait pembuatan gugatan atau permohonan. Staf dari posbakum akan membantu membuatkan surat gugatan secara sukarela, dalam proses pembuatannya pun tidak dikenakan biaya.

Cara ketiga, melalui pengacara baik sifatnya profesional maupun insidentil. Kuasa professional yang dimaksud adalah pengacara atau advokat yang mendampingi pemohon atau penggugat dalam menangani perkara yang sedang dihadapinya. Sementara kuasa insidentil adalah kuasa yang diberikan kepada 
keluarga atau keturunan nasab untuk mewakili persidangan yang sedang berlangsung. ${ }^{16}$

Pernyatakan Syukur, S.Ag., M.H., jika disimpulkan terdapat 2 (dua) macam bantuan hukum yaitu legal aid, merupakan bantuan hukum yang diberikan khusus secara pro deo atau cuma-Cuma, dan legal assistance yaitu bantuan hukum yang diberikan kepada orang yang mampu membayar jasa pemberi bantuan hukum. Dalam hal ini, KUHAP secara eksplisit tidak membedakan antara legal aid dan legal assistance, namun di dalam pasal-pasal yang mengatur mengenai bantuan hukum, yakni: pasal 54-57 dan pasal 60-62 (pada Bab VI tentang Tersangka dan Terdakwa); pasal 69-74 (pada Bab VII tentang Bantuan Hukum); pasal 114-115 (pada Bab XIV tentang Penyidikan); selain diatur mengenai kegiatan bantuan hukum secara umum, secara khusus di dalam pasal 56 telah diatur juga mengenai bantuan hukum yang wajib dijalankan serta diberikan secara cuma-cuma atau pro deo.

Terkait eksistensi Posbakum yang membantu mereka yang tidak mampu yang sifatnya legal aid, berdasarkan data hasil wawancara yang dilakukan di Pengadilan Agama Tanjung Karang Kelas 1A dinilai masyarakat sangat membantu dalam berbagai hal. Di antaranya yang didapat hasil wawancara. Pertama, membantu menyelesaikan persoalan hukum.Bagi mereka yang tidak mengerti tentang hukum, kehadiran Posbakum di Pengadilan Agama Kelas 1A Tanjung Karang, sangat membantu dalam proses menyelesaikan persoalan hukum. Sebagaimana dari pernyataan Hasanah (43 tahun) beralamat di Tanjung Gading, Kedamaian. Ia merasa terbantu dengan adanya Posbakum dalam membuat surat gugatan, karena dirinya mengakui tidak paham dengan hukum. Sebagaimana pernyataan lengkapnya sebagai berikut:

"Saya berterimakasib kepada Bapak (Staff Posbakum) yang telah membantu saya membuatkan surat gugatan cerai. Saya jujur, tidak, pabam dengan bukum. Sehingga dengan adanya ini (Posbakum) urusan saya bisa selesai”."7

Kedua, menekan pengeluaran keuangan. Selain membantu menyelesaikan persoalan hukum bagi mereka yang tidak memahami hukum, kehadiran Posbakum juga membantu menekan pengeluaran keluarga. Hal ini diungkapkan Tria (36 tahun) beralamat di Kemiling. Tria yang memiliki beberapa anak merasa terbantu dengan adanya Posbakum terutama terkait masalah hukum. Selain itu juga, dengan adanya Posbakum, dapat menekan pengeluaran keuangan keluarga. Sebagaimana pernyataan lengkapnya:

16 Wawancara dengan Panitera Muda Hukum, Syukur, S.Ag., M.H., pada Rabu 15 November 2017.

${ }^{17}$ Wawancara dengan Hasanah, pengguna jasa Posbakum, pada Kamis, 16 November 2017. 
"Saya tidak mengerti bukum. Bingung harus bagaimana menyelesaikan persoalan keluarga saya. Sementara saya ingin cerai. Membuat surat gugatan sendiri saya tidak bisa. Saya berterimakasib dengan adanya Posbakum karena membantu saya membuatkan surat gugatan. Selain itu, dengan adanya Posbakum ini, membantu saya menekan keuangan keluarga. Karena di sini melalui Posbakum tidak dikenakan biaya, sementara kalau di luar (memakai bantuan pengacara) harus bayar. Di sisi lain anak saya banyak. Dengan adanya ini (Posbakum) biaya yang seharusnya untuk pengacara, bisa untuk anak-anak saya. Apalagi anak saya berjumlah tiga orang yang butub biaya banyak. Anak pertama kelas 3 SMP, anak kedua kelas 4 SD, dan anak ketiga kelas 3 SD."18

Ketiga, kehadiran Posbakum mempermudah dan mempercepat menyelesaikan persoalan hukum.Kehadiran Posbakum di Pengadilan Agama Kelas 1A Tanjung Karangdirasakan masyarakat sangat membantu dan tidak membuat ribet dalam menyelesaikan persoalan hukum. Hal ini diungkapkan Mariani (43 tahun) beralamat di Kampung Baru Raya, Kedaton. Ia menyatakan dengan adanya Posbakum mempermudah dirinya untuk mengggugat cerai sekaligus mempermudah dirinya untuk mencabut gugatan cerainya. Sebagaimana pernyataan lengkapnya:

"Dengan adanya Posbakum membuat saya tidak ribet dalam proses membantu persoalan bukum yang sedang saya jalani. Membuat surat gugatan juga mudah dan cepat. Mencabutnya pun mudah. Ini yang saya alami. Sekarang saya mencabut lagi surat gugatan saya karena anak saya tidak terima saya cerai. Anak saya meminta, kalau ingin cerai harus keinginan suami saya, bukan keinginan saya. Sebingga saya cabut gugatan saya."19

Selain Mariani, kehadiran Posbakum yang dinilai mempermudah proses dalam menyelesaikan persoalan perceraian, dirasakan Nova Purnamasari (24 tahun) yang beralamat di Tamin. Ia menilai dengan adanya Posbakum ini mempermudah dan mempercepat proses perceraiannya. Sebagaiman pernyataan lengkapnya:

"Saya memakai Posbakum dalam menyelesaikan persoalan perceraian saya biar cepat selesai. Biar lebih mudah juga. Sehingga surat gugatan saya dapat cepat diproses. Saya ingin segera bercerai. Karena saya sudah berpisah dengan suami saya sudah satu tabun lebih, sementara saya sudah mempunyai anak yang baru 4 tabun. Anak saya sekarang tinggal bareng saudara saya. Kalau saya sudah cerai, kan resmi cerainya memudabkan saya untuk, menikah lagi. Takutnya ada jodoh, dan ada yang mau menikahi saya, kalau sudah resmi kan enak menikahnya. Saya tidak mau nikah sirri. Saya pengen resmi. Cerai resmi, dan nikah lagi pun resmi." ${ }^{20}$

2017.

${ }^{18}$ Wawancara dengan Tria, pengguna jasa Posbakum, pada Kamis, 16 November 2017.

19 Wawancara dengan Mariani, pengguna jasa Posbakum, pada Kamis, 16 November

${ }^{20}$ Wawancara dengan Nova Purnamasari, pengguna jasa Posbakum, pada Kamis, 16 November 2017. 
Terkait hal yang dirasakan oleh pengguna jasa Posbakum bagi mereka yang akan menyelesaikan perkara hukum di Pengadilan Agama Kelas 1A Tanjung Karang, sesuai dengan apa yang dinyatakan Ahmad Burhanuddin, S.H.I, M.H.I. Ia menyatakan eksistensi Posbakum yang merupakan bagian dari pelayanan bantuan hukum berperan dalam membantu pelayanan hukum. Hal ini sesuai dengan Undang-Undang nomor 16 tahun 2011 dan sesuai juga dengan Perma Nomor 1 Tahun 2014 pasal 22. Dimana pelayanan hukum dilakukan oleh Posbakum, sidang keliling, dan pemberian bantuan hukum bagi yang tidak mampu.

Posbakum berperan membantu menyelesaikan persoalan hukum di antaranya menjadi tempat konsultasi hukum, pembuatan dokumen-dokumen hukum dan pendampingan bagi orang yang tidak mampu/perkara prodeo. Hanya saja menurut Ahmad Burhanuddin, S.H.I, M.H.I., selama dirinya bekerja di Posbakum selama dua tahun di Pengadilan Agama Kalianda dan Pengadilan Agama Kelas 1A Tanjung Karang hanya melayani konsultasi dan pembuatanpembuatan dokumen. Dalam hal pendampingan tidak dilakukan, karena perkara-perkara yang terjadi di Pengadilan Agama Kalianda dan Pengadilan Agama Kelas 1A Tanjung Karang bersifat ringan, berbeda dengan Pengadilan Negeri yang banyak menangani perkara berat seperti perkara pidana. Jika perkara pidana perlu adanya pendampingan. Pendampingan perkara-perkara tersebut menurutnya, dibebankan oleh anggaran DIPA Pengadilan Agama setempat.

Hasil analisis yang dilakukan Ahmad Burhanuddin, S.H.I, M.H.I., konsultasi hukum yang banyak dilakukan di Posbakum Pengadilan Agama Kelas 1A Tanjung Karang terdapat beberapa hal. Pertama, persoalan kewarisan yakni persoalan penetapan ahli waris. Mereka biasanya berkonsultasi terkait berkasberkas yang perlu dilengkapi dalam proses penetapan ahli waris. Kedua, isbat nikah. Persoalan ini juga kerap dikonsultasikan oleh pemakai jasa Posbakum. Ketiga, persoalan perwalian. Hal ini terkait tindakan hukum bagi anak yang belum dewasa yakni anak yang berumur di bawah 21 tahun atau belum menikah. Dalam kaitanya hal ini, perwalian yang dikonsultasikan adalah terkait penetapan wali. Keempat, konsultasi terkait perceraian. Persoalan perceraian, menurutnya, persoalan ringan dan pokok persoalannya juga termasuk hal biasa. Kelengkapan berkasnya pun tidak menjadi kendala bagi pemakai jasa Posbakum. ${ }^{21}$

Hal yang dilakukan oleh Posbakum Pengadilan Agama Kelas 1 Tanjung Karang merupakan bagian dari pengamalan Pasal 27 ayat (1) Amandemen Undang-undang Dasar 1945 yang menyebutkan bahwa segala warga negara bersamaan kedudukannya di dalam hukum dan pemerintahan dan wajib

21 Wawancara dengan Ahmad Burhanuddin, S.H.I., M.H.I., pengacara Posbakum Pengadilan Agama Klas 1A Kota Bandar Lampung pada Rabu 15 November 2017. 
menjunjung hukum dan pemerintahan itu dengan tidak ada kecualinya. Artinya segala warga negara, tidak dibedakan apakah miskin atau kaya, maka tetap mendapat perlakuan yang sama dalam proses menyelesaikan masalah hukum di pengadilan, mempunyai hak-hak yang sama, perlakuan yang sama, tanpa ada diskriminasi. Sehingga sudah sewajarnya pemberian bantuan hukum adalah hak setiap warga Negara dengan tidak ada kecualinya.

Kehadiran Posbakum juga merupakan sarana bagi warga Negara untuk mendapatkannya agar dibela oleh penasehat hukum (access to legal council) dalam menghadapi masalah hukum dan memperoleh perlakuan yang sama dalam menyelesaikan masalah hukum yang dihadapinya (equality before the law). Perihal bantuan hukum, termasuk Posbakum, memakai prinsip equality before the law dan access to legal council dan di dalam hukum positif Indonesia telah diatur secara jelas dan tegas dalam berbagai peraturan perundang-undangan.

Selain itu, bantuan hukum untuk orang miskin adalah tugas negara dan pemerintah seperti yang diamanahkan oleh konsitusi. Pasal 28D ayat (U) menyatakan bahwa setiap orang berhak atas pengakuan, jaminan, perlindungan, dan kepastian hukum yang adil; serta perlakuan yang sama di hadapan hukum. Harus diakui, selama ini pemberian Bantuan Hukum yang dilakukan belum banyak menyentuh orang atau, kelompok orang miskin oleh karena itu negara bertanggung jawab terhadap pemberian bantuan hukum bagi orang miskin sebagai perwujudan akses terhadap keadilan (accses to justice).

Harus diakui pula, sebagaimana dinyatakan oleh pengguna jasa Posbakum di atas, pelaksanaan program Pos Bantuan Hukum (Posbakum) di berbagai pengadilan baik pengadilan negeri, pengadilan agama maupun pengadilan tata usaha negara ini dirasa cukup efektif karena sebagian besar masyarakat Indonesia sungkan untuk menceritakan permasalahan hukum yang dihadapinya. Selain itu, faktor pemikiran bahwa apabila melakukan konsultasi bahkan sampai pada tingkat permohonan bantuan hukum di kantor advokat pasti akan menghabiskan biaya yang sangat besar. Dengan program Pos Bantuan Hukum(Posbakum)ini, masyarakat tidak dikenakan biaya sama sekali.

Mekanisme Pelaksanaan, dan Proses Mendapatkan Jasa Bantuan Hukum Probono Legal Aid Menurut UU No. 16 Tahun 2011 tentang Bantuan Hukum Dalam proses mendapatkan jasa bantuan hukum, pemohon terlebih dahulu ke meja 1 (satu), yakni meja penerimaan informasi. Di meja informasi, pemohon mengisi formulir pernyataan tidak mampu membayar advokat dan pemohon untuk dibuatkan di Posbakum. Dari Posbakum, dokumen yang telah dibuatkan dirangkap tujuh bertandatangan basah, kemudian ke meja 1 (satu) lagi agar terdaftar dan terregistrasi. Dari meja 1 (satu) kembali ke Posbakum untuk diarsipkan.

Hal ini sebagaimana dinyatakan Andriko (29 tahun) beralamat di Gedong Meneng. Menurutnya, proses yang dilalui ke meja 1 (satu) dulu 
kemudian dilanjutkan ke meja Posbakum untuk berkonsultasi terhadap perkara yang sedang dihadapinya:

"Awalnya saya konsultasi ke depan (meja 1) untuk mengajukan permobonan cerai. Di sana (meja 1) ditanya, mengajukan permohonan cerai sendiri, melalui pengacara atau di sini (Posbakum)?. Karena saya sendiri tidak tabu menahu dengan bukum. Kalau melalui pengacara tambah ribet. Jadi saya ke sini (Posbakum) untuk mempermudah persoalan yang sedang saya badapi yakni permohonan untuk cerai. Saya juga mendapat araban dari Bapak (staf Posbakum) tadi untuk melakukan permohonan cerai di Bekasi, karena istri saya tinggal di Bekasi. Jadi, adanya ini (Posbakum) membantu saya sekaligus memberikan informasi tentang bukum kepada saya, yang saya sendiri tidak mengerti tentang bukum."22

Berdasarkan hal tersebut, kehadiran Posbakum untuk membantu mereka yang tidak mengerti tentang prosedur hukum dan mereka yang tidak mampu membayar jasa hukum sangat terbantu. Sebab sebagaimana dalam sejarahnya, lahirnya UU Bantuan Hukum menjadi wujud nyata tanggung jawab negara terhadap Hak Atas Bantuan Hukum sebagai akses keadilan bagi seluruh masyarakat Indonesia sebagaimana diamanahkan oleh UUD 1945, UU Nomor 39 tahun 1999 tentang Hak Asasi Manusia (HAM), Kitab Undang-undang Hukum Acara Pidana (KUHAP), Deklarasi Universal Hak Asasi Manusia, pasal 14 (3) (d) Kovenan Internasional tentang Hak-Hak Sipil dan Politik (International Covenant on Civil and Political Rights) yang telah disahkan melalui Undang-Undang Nomor 12 tahun 2005, juga ada pemberian jaminan bagi setiap orang untuk mendapatkan bantuan hukum dan pelayanan dari Advokat ( a right to have a legal counsel) yang berkualitas bagi masyarakat miskin. Sesuai praktek internasional, ada 5 pilar mengenai bantuan hukum yakni accesible (bantuan hukum harus dapat diakses dengan mudah), affordability (bantuan hukum dibiayai oleh Negara), sustainable (bantuan hukum harus terus ada dan tidak tergantung pada donor sehingga negara harus menganggarkannya dalam APBN), credibility (bantuan hukum harus dapat dipercaya dan memberikan keyakinan bahwa yang diberikan adalah dalam rangka peradilan yang tidak memihak (juga saat mereka menghadapi kasus melawan negara, tidak ada keraguan tentang itu)), serta accountability (pemberi bantuan hukum harus dapat memberikan pertanggungjawaban keuangan kepada badan pusat dan kemudian badan pusat harus mempertanggungjawabkan kepada parlemen).

Meskipun kehadiran Posbakum membantu masyarakat yang tidak mampu, namun dirinya menemukan beberapa hal yang menjadi perhatiannya selama membantu masyarakat yang tidak mampu baik sifatnya positif maupun kritik konstruktif. Hal tersebut bukan hanya persoalan yang didapatnya dari masyarakat yang memakai jasa bantuannya, namun juga terkait regulasi yang 
diterapkan pemerintah terkait eksistensi Posbakum. Pertama, karena sifatnya kontrak sebagai pemenang lelang, maka harus dijalankan selama satu tahun terhitung bulan April sampai Desember 2017. Jika dihitung bulan, maka tidak genap satu tahun melaksanakan tugas tersebut karena dipotong masa lelang. Selain itu, tahun selanjutnya akan diperbaharui. Perbaharuan tersebut disesuaikan dengan regulasi atau edaran yang dikeluarkan Mahkamah Agung Republik Indonesia, bisa melalui lelang atau bisa juga melalui penunjukan.

Kedua, kehadiran Posbakum sebagai media pembelajaran bagi sarjana hukum. Karena banyak sekali persoalan-persoalan di lapangan yang berbedabeda terkait alasan perceraian, termasuk persoalan cerai yang dianggap masyarakat merupakan hal sepele ternyata bisa menyebabkan perceraian. Ketiga, minimnya pemahaman hukum bagi pemakai jasa Posbakum. Hal ini seperti kendala mereka yang datang tidak mengerti perkara yang diajukan. Sejatinya perkara diajukan di tempat wanita tinggal, misalnya, sebagai bagian dari kompetensi relatif Pengadilan Agama, justru pemohon mengajukannya di Pengadilan Agama Kelas 1A Tanjung Karang.

Keempat, kendala teknis pemohon. Hal ini seperti pemohon yang tidak bisa baca tulis. Hal ini seperti seseorang yang melakukan isbat nikah. Teks atau dokumennya sudah dibuatkan oleh Posbakum dan ditandatangani hakim. Sejatinya dokumen tersebut dibacakan oleh yang bersangkutan, karena yang bersangkutan tidak bisa membaca, akhirnya dokumen tersebut dibacakan oleh hakim.Kelima, Posbakum menjadi aplikasi dan implementasi mata kuliah yang pernah diajarkan ketika menjadi mahasiswa. ${ }^{23}$

\section{Penutup}

Faktor-faktor yang melatarbelakangi pencari keadilan masyarakat menengah ke bawah yang memakai jasa bantuan hukum probono legal aid melalui Posbakum di Pengadilan Agama Kelas 1A Tanjung Karang Kota Bandar Lampung sangat beragam. Faktor minimnya pemahaman hukum menjadi salah satu sebab masyarakat memutuskan memakai jasa Posbakum. Faktor dapat lebih mempermudah dan mempercepat dalam menyelesaikan persoalan hukum yang sedang dihadapi masyarakat, menjadi pilihan dalam memutuskan memakai jasa Posbakum. Faktor efesiensi menjadi salah satu pilihan masyarakat dalam menggunakan jasa Posbakum. Melalui jasa Posbakum, masyarakat yang tidak memiliki anggaran dapat terbantu, sebab sebagian besar pemikiran masyarakat, jika menggunakan jasa advokat dinilai akan menghabiskan biaya yang cukup besar.

23 Wawancara dengan Ahmad Burhanuddin, S.H.I., M.H.I., pengacara Posbakum Pengadilan Agama Klas 1A Kota Bandar Lampung pada Jumat, 17 November 2017. 


\section{Daftar Pustaka}

Afandi, Fachrizal. "Implementasi Pengabdian Masyarakat Berbasis Acces to Justice pada Lembaga Bantuan Hukum Kampus Negeri Pasca Pemberlakukan Undang-Undang Bantuan Hukum". Jurnal RechtsVinding: Media Pembinaan Hukum Nasional, Vol. 2, No. 1, (2013).

Atikah, Nisrina, Nurul Mutmainnah, Arif Rachman Nur. "Legal Aid Democracy: Pengembalian Entitas Bantuan Hukum dalam Mewujudkan Aksesibilitas Hukum Bagi Masyarakat Indonesia dan Pembangunan Hukum Nasional”. Universitas Hasanuddin Makassar 2015.

Direktorat Pembinaan Peradilan Agama Departemen Agama. Buletin Berkala Hukum dan Peradilan. Jakarta: Departemen Pembinaan Badan Peradilan Agama Departemen Agama, 2002.

Hadi, Sutrisno. Metodologi Research. Jilid I. Yogyakarta: PT. Andi Offset, 1989. Irwantoni, Chaidir Nasution, Abdul Qodir Zaelani. "Peranan Bantuan Hukum dalam Menyelesaikan Perkara di Pengadilan Agama (Studi di Pengadilan Agama Kelas IA Tanjungkarang Bandar Lampung)". Asas, Vol 10, No 01 (2018).

Rahmat, Diding. "Implementasi Kebijakan Program Bantuan Hukum Bagi Masyarakat Tidak Mampu di Kabupaten Kuningan". Jurnal Unifikasi, Vol. 04 No 01 (2017).

Saefudin, Yusuf. "Implementasi Pemberian Bantuan Hukum bagi Rakyat Miskin di Jawa Tengah Berdasarkan Undang-Undang Nomor 16 Tahun 2011 Tentang Bantuan Hukum”. Jurnal Idea Hukum,Vol 1, No 1 (2015).

Simbolon, Laurensius Arliman. "Partisipasi Masyarakat di dalam Perlindungan Anak yang Berkelanjutan Sebagai Bentuk Kesadaran Hukum". Padjajaran Jurnal Ilmu Hukum, Vol 3, No. 2, (2016).

Susanti, Ersa, Adelina Hasyim, Yunisca Nurmalisa. "Pemahaman Masyarakat Terhadap Pembagian Waris Menurut Hukum Waris Islam di Desa Banjar Ratu”. http://jurnal.fkip.unila.ac.id, Vol. 5, No. 4, (2017).

Sumadi, Ahmad Fadlil. "Hukum dan Keadilan Sosial dalam Perspektif Hukum Ketatanegaraan Law and Social Justice in Constitutional Law Perspective". Jurnal Konstitusi, Vol 12, No 4 (2015).

Taufik, Ade Irawan. "Sinergitas Peran dan Tanggungjawab Advokat dan Negara dalam Pemberian Bantuan Hukum Cuma-cuma". Jurnal RechtsVinding: Media Pembinaan Hukum Nasional, Vol. 2 No. 2, (2013).

Wijayanta, Tata. "Bantuan Hukum Golongan Tidak Mampu dalam Perkara Perdata di Pengadilan Negeri Yogya". Mimbar Hukum, Vol 24, No 1 (2012).

Wawancara dengan Panitera Muda Hukum, Syukur, S.Ag., M.H., pada Rabu 15 November 2017. 
Wawancara dengan Ahmad Burhanuddin, S.H.I., M.H.I., pengacara Posbakum Pengadilan Agama Kelas 1A Kota Bandar Lampung pada Rabu 15 dan 17 November 2017.

Wawancara dengan Hasanah, pengguna jasa Posbakum, pada Kamis, 16 November 2017.

Wawancara dengan Tria, pengguna jasa Posbakum, pada Kamis, 16 November 2017.

Wawancara dengan Mariani, pengguna jasa Posbakum, pada Kamis, 16 November 2017.

Wawancara dengan Nova Purnamasari, pengguna jasa Posbakum, pada Kamis, 16 November 2017.

Wawancara dengan Andriko, pengguna jasa Posbakum, pada Jumat, 17 November 2017. 